\title{
Frozen ponds: production and storage of methane during the Arctic winter in a lowland tundra landscape in northern Siberia, Lena River delta
}

\author{
M. Langer ${ }^{1}$, S. Westermann ${ }^{2,3}$, K. Walter Anthony ${ }^{4}$, K. Wischnewski ${ }^{1}$, and J. Boike ${ }^{1}$ \\ ${ }^{1}$ Alfred-Wegener-Institut Helmholtz-Zentrum für Polar- und Meeresforschung, Periglacial \\ Research Section, Potsdam, Germany \\ ${ }^{2}$ Department of Geography, University of Oslo, Oslo, Norway \\ ${ }^{3}$ Center for Permafrost (CENPERM), Department of Geosciences and Natural Resource Management, \\ University of Copenhagen, Copenhagen, Denmark \\ ${ }^{4}$ University of Alaska Fairbanks, Water and Environmental Research Center, Fairbanks, USA \\ Correspondence to: M. Langer (moritz.langer@awi.de)
}

Received: 9 June 2014 - Published in Biogeosciences Discuss.: 18 July 2014

Revised: 21 January 2015 - Accepted: 21 January 2015 - Published: 17 February 2015

\begin{abstract}
Lakes and ponds play a key role in the carbon cycle of permafrost ecosystems, where they are considered to be hotspots of carbon dioxide $\mathrm{CO}_{2}$ and methane $\mathrm{CH}_{4}$ emission. The strength of these emissions is, however, controlled by a variety of physical and biogeochemical processes whose responses to a warming climate are complex and only poorly understood. Small waterbodies have been attracting an increasing amount of attention since recent studies demonstrated that ponds can make a significant contribution to the $\mathrm{CO}_{2}$ and $\mathrm{CH}_{4}$ emissions of tundra ecosystems. Waterbodies also have a marked effect on the thermal state of the surrounding permafrost; during the freezing period they prolong the period of time during which thawed soil material is available for microbial decomposition.

This study presents net $\mathrm{CH}_{4}$ production rates during the freezing period from ponds within a typical lowland tundra landscape in northern Siberia. Rate estimations were based on $\mathrm{CH}_{4}$ concentrations measured in surface lake ice from a variety of waterbody types. Vertical profiles along ice blocks showed an exponential increase in $\mathrm{CH}_{4}$ concentration with depth. These $\mathrm{CH}_{4}$ profiles were reproduced by a 1-D mass balance model and the net $\mathrm{CH}_{4}$ production rates were then inferred through inverse modeling.

Results revealed marked differences in early winter net $\mathrm{CH}_{4}$ production among various ponds. Ponds situated within intact polygonal ground structures yielded low net pro-
\end{abstract}

duction rates, of the order of $10^{-11}$ to $10^{-10} \mathrm{~mol} \mathrm{~m}^{-2} \mathrm{~s}^{-1}$ (0.01 to $\left.0.14 \mathrm{mg}_{\mathrm{CH}_{4}} \mathrm{~m}^{-2} \mathrm{day}^{-1}\right)$. In contrast, ponds exhibiting clear signs of erosion yielded net $\mathrm{CH}_{4}$ production rates of the order of $10^{-7} \mathrm{molm}^{-2} \mathrm{~s}^{-1}\left(140 \mathrm{mg}_{\mathrm{CH}_{4}} \mathrm{~m}^{-2} \mathrm{day}^{-1}\right)$. Our results therefore indicate that once a particular threshold in thermal erosion has been crossed, ponds can develop into major $\mathrm{CH}_{4}$ sources. This implies that any future warming of the climate may result in nonlinear $\mathrm{CH}_{4}$ emission behavior in tundra ecosystems.

\section{Introduction}

Up to $28 \%$ of the land surface in permafrost landscapes has been attributed to lakes and ponds (Emmerton et al., 2007; Grosse et al., 2008; Muster et al., 2013). Several studies have emphasized that waterbodies are fundamental elements in Arctic ecosystems and exert strong control over the Arctic heat, water, and carbon cycles (Cole et al., 2007; McGuire et al., 2009). This is especially true in permafrost landscapes, where large quantities of carbon are trapped in the frozen soils that can surround waterbodies (e.g., Hugelius et al., 2013). Any future mobilization and emission of the old carbon pool is likely to result in a positive feedback to global warming (O'Connor et al., 2010; Koven et al., 2011). 
Lakes are considered to play a key role in the turnover and emission of the carbon in these permafrost reservoirs (Boike et al., 2012). Many of the studies to date have focused on the greenhouse gas emission potential of large lakes such as thermokarst lakes (Zimov et al., 1997; Walter K. M. et al., 2006; Brosius et al., 2012). However, recent studies have demonstrated that not only large Arctic lakes, but also the smaller Arctic ponds, are hotspots of $\mathrm{CO}_{2}$ and $\mathrm{CH}_{4}$ emission (Abnizova et al., 2012; Laurion et al., 2010). In lowland tundra landscapes such as the Lena River delta, more than $30 \%$ of the total inland water surface can be attributed to waterbodies with surface areas less than $1 \mathrm{~km}^{2}$ (Muster et al., 2012). Most studies to date addressing greenhouse gas emissions from Arctic ponds have focused on the summer months but a considerable carbon turnover is also possible in waterbodies during the freezing period, until the bottom sediments are completely frozen (Karlsson et al., 2013). During winter, the closed ice cover inhibits the diffusion of oxygen into the water which strongly limits the oxidation of $\mathrm{CH}_{4}$ in the water column. Several studies have demonstrated that large quantities of $\mathrm{CH}_{4}$ are produced during the long-lasting winter period and stored in the form of bubbles within the ice cover (Walter Anthony et al., 2010; Wik et al., 2011; Boereboom et al., 2012; Walter Anthony and Anthony, 2013).

Bubbles trapped in lake ice, resulting from a number of different processes, include ebullition bubbles, bubbles from freeze-degassing of dissolved gases, and photosynthesis bubbles. These can usually be distinguished from each other on the basis of their size, morphology, and gas content (Boereboom et al., 2012; Walter Anthony and Anthony, 2013). This study focuses on $\mathrm{CH}_{4}$ which is stored in the form of bubbles from freeze-degassing, which are continuously formed at the advancing freezing front and occur in closely spaced layers in the ice cover (Lipp et al., 1987). Due to freeze-degassing dissolved gases enrich in a very thin water layer directly at the freezing front. The saturation of dissolved gases in this thin water layer leads to bubble nucleation. The gas concentration in the growing bubbles is in equilibrium with the dissolved gases of the surrounding water (Wei et al., 2003). As soon as the bubbles are completely entrapped within the ice cover they are sealed from further gaseous exchange so that an enrichment of dissolved gases and bubble nucleation at the freezing front starts again. This results in the continuous formation of freeze-out bubble layers which preserve, to a certain degree, information about the concentration of the dissolved gases in the water column during the time of freezing (Lipp et al., 1987; Craig et al., 1992; Killawee et al., 1998). The frequency of bubble layer formation, bubble size, and bubble shape are largely dependent on the rate of freezing (Carte, 1961; Yoshimura et al., 2008). The sizes of freezeout bubbles are reported to range between micrometers to millimeters at natural freezing rates of the order of millimeters per day (Lipp et al., 1987; Yoshimura et al., 2008).

The storage of $\mathrm{CH}_{4}$ within the ice cover of shallow Alaskan lakes has been investigated by Phelps et al. (1998).
They found that $\mathrm{CH}_{4}$ concentrations were very low in the upper part of the ice cover, but increased rapidly with depth. This behavior was explained by supersaturation of dissolved gases due to the shrinking volume of available water underneath the growing ice cover. In addition, the concentration of dissolved $\mathrm{CH}_{4}$ was observed to increase at the ice-water interface over the winter period. However, it remains unclear whether this $\mathrm{CH}_{4}$ accumulation in the shrinking water column was caused by freeze-degassing of $\mathrm{CH}_{4}$, ongoing $\mathrm{CH}_{4}$ production during ice cover formation, or a combination of both. In addition, Phelps et al. (1998) also found that the $\mathrm{CH}_{4}$ stored in the ice cover was largely released into the atmosphere during spring melt. Furthermore, they were able to show that the amount of $\mathrm{CH}_{4}$ emitted in spring equated to half of the total annual $\mathrm{CH}_{4}$ emissions from the lake. These results served to further stress the importance of the freezing period to the carbon cycle of tundra-lake ecosystems.

In this study, we present profiles derived from measurements of $\mathrm{CH}_{4}$ concentrations in the ice cover of nine typical Arctic ponds and lakes in the Lena River delta of northeastern Siberia. An extensive survey of pond areas and depths has provided insights into the development stages of the various waterbodies within the area of investigation. Temperature profiles were derived from measurements in three different ponds and used to investigate their freezing behavior. A 1-D mass balance model was developed to reconstruct the storage of $\mathrm{CH}_{4}$ within the ice cover, and the $\mathrm{CH}_{4}$ concentration profiles (derived from $\mathrm{CH}_{4}$ concentration measurements in the ice cover) were used to infer net $\mathrm{CH}_{4}$ production rates during the freezing period by inverse modeling. For the first time, this allows one to distinguish between $\mathrm{CH}_{4}$ accumulation caused by freeze-degassing and ongoing $\mathrm{CH}_{4}$ production during freeze-up.

\section{Study area}

The study area is located in the Lena River delta of northeastern Siberia, within the zone of continuous permafrost (Fig. 1). The region is characterized by an Arctic continental climate with a mean annual air temperature of about $-14^{\circ} \mathrm{C}$. Winter temperatures frequently fall below $-45^{\circ} \mathrm{C}$ while summer temperatures can exceed $25^{\circ} \mathrm{C}$ (Langer et al., 2011a; Boike et al., 2013). The cold climate results in very cold permafrost temperatures: an annual average temperature of about $-9^{\circ} \mathrm{C}$ has been recorded at a depth of $27 \mathrm{~m}$ (Boike et al., 2013). Permafrost in the Lena River delta region is reported to extend to depths of several hundred meters (Grigoriev, 1960). The study area is located on Samoylov Island in the central part of the Lena River delta $\left(72^{\circ} 22^{\prime} \mathrm{N}, 126^{\circ} 28^{\prime} \mathrm{E}\right)$. The island is mainly characterized by a Holocene cryogenic soil complex that is largely characterized by the typical micro-relief of polygonal patterned ground formed by frost cracking and subsequent icewedge formation (Lachenbruch, 1962). The polygonal struc- 


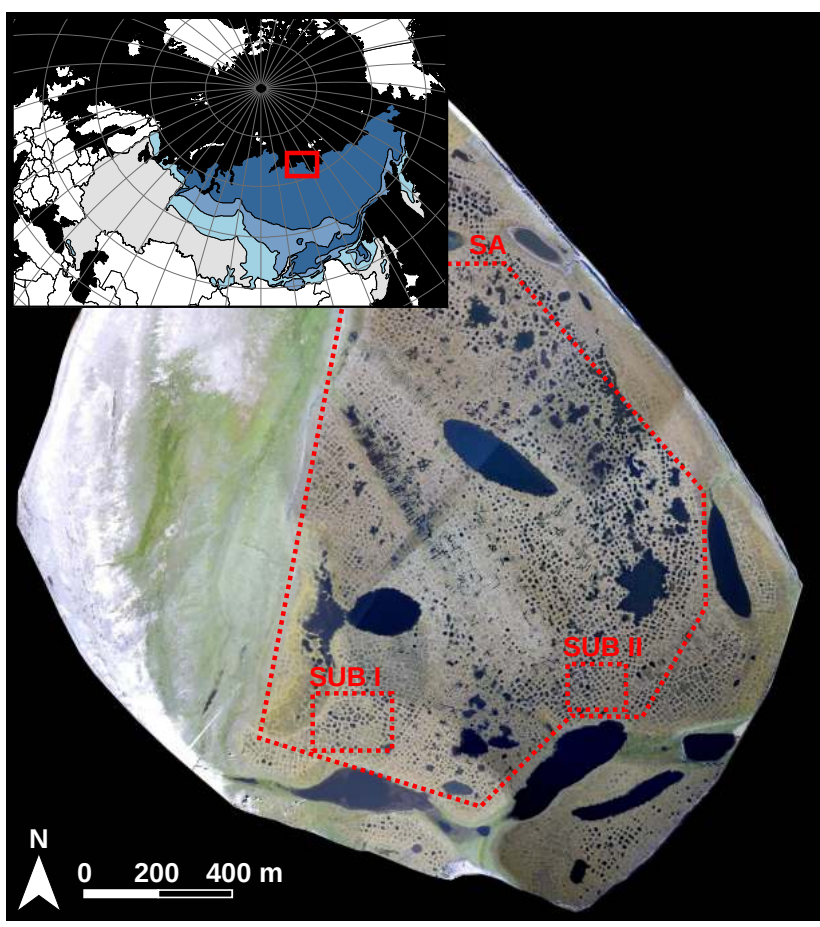

Figure 1. Location of the study area in northern Siberia within the zone of continuous permafrost (a) (map after Brown et al., 1997), and ortho-rectified aerial image of Samoylov Island (b). The main study area (SA) and the two sub-areas (SUB I, SUB II) used for the pond and lake mapping and for sampling are outlined in red.

tures usually consist of depressed, water-saturated centers surrounded by elevated rims. The soil in the polygonal centers usually consists of sandy peat while the elevated rims are usually covered with a dry moss layer underlain by wet sandy peat soils and massive ice wedges (Kutzbach et al., 2004). The gravimetric content of soil organic carbon was measured to range from about 1 to $24 \%$ at the study site (Zubrzycki et al., 2013). The polygonal ground structures are present in different stages of degradation. Ponding water is often found in the depressed polygon centers (intra-polygonal ponds) or along the troughs between the polygon rims above the ice-wedges (ice-wedge ponds; Fig. $2 \mathrm{a}$, b; Wetterich et al., 2008; Helbig et al., 2013; Negandhi et al., 2013). Both intrapolygonal ponds and ice-wedge ponds are usually very shallow, with water depths ranging from just a few centimeters to a few tens of centimeters. Such ponds often feature emergent vegetation, consisting mainly of hydrophilic species such as Carex aquatilis and mosses such as Scorpidium scorpioides (Kutzbach et al., 2007; Liebner et al., 2011). The rims surrounding intra-polygonal ponds are mostly intact with little or no sign of degradation. However, degradation of the polygonal structures can result in ponds merging to form larger ponds that often consist of several polygons, typically showing clear signs of degradation (Fig. 2 c; Helbig et al., 2013). They feature open water surfaces and lack emergent vege- tation in their centers. The study area is also characterized by thermokarst (thaw) lakes, which are a result of advanced permafrost degradation associated with further thermal erosion processes (Morgenstern et al., 2013). About $50 \%$ of the free water surface on Samoylov Island is attributed to ponds, with the remaining $50 \%$ attributed to lakes, including both thermokarst lakes and oxbow lakes (Muster et al., 2012).

\section{Methods and materials}

\subsection{Pond survey and classification}

The distribution and sizes of waterbodies within the study area were mapped using ortho-rectified, visual and nearinfrared aerial images. The study area (SA) lies on the first terrace of Samoylov Island and covers a typical wet lowland tundra landscape; it has a surface area of about $1.5 \mathrm{~km}^{2}$ (Fig. 1). We used the supervised surface water classification from Muster et al. (2012) to extract a size distribution for the ponds and lakes within the area. Water depth measurements were also collected from two sub-areas (SUB I and SUB II), each of which had a surface area of about $30000 \mathrm{~m}^{2}$ (Fig. 1). The water depths were measured manually using a depth sounder, or a ruler where the water levels were very low.

In this study, we mainly focused on small waterbodies (ponds) smaller than $10000 \mathrm{~m}^{2}$. On the basis of morphology we distinguish between ice-wedge ponds (Fig. 2 a), intrapolygonal ponds (Fig. 2a), and merged ponds (Fig. 2 c). These ponds are further grouped into initial state ponds (ISPs) and advanced state ponds (ASPs) according to the degrees of degradation of the polygonal ground structures within which the ponds occur. ISPs are defined as ponds that occur within almost intact polygonal structures; they include both ice-wedge ponds located between polygon rims (Fig. 2a) and intra-polygonal ponds located in polygon centers (Fig. 2b). ISPs are shallow with water depths of less than $0.5 \mathrm{~m}$. Their horizontal extent typically ranges from a few meters up to about $10 \mathrm{~m}$, which is a typical diameter for the polygonal structures. Due to initial degradation ISPs can be hydrologically interconnected with other ISPs or with larger waterbodies, but the individual polygon shape is still preserved. In contrast, ASPs show clear signs of degradation in the surrounding polygonal tundra (Fig. 2c). The center of an ASP is much deeper due to thaw settlement in the underlying bottom sediments so that ASPs usually have water depths greater than $0.5 \mathrm{~m}$. ASPs typically range in diameter from about 10 to $50 \mathrm{~m}$. Waterbodies that reach depths greater than $2 \mathrm{~m}$ are likely to remain unfrozen at the bottom throughout the winter, and a continuously unfrozen layer (talik) then develops in the sediments. These deeper waterbodies are usually larger, with horizontal extent ranging from about $50 \mathrm{~m}$ to several hundreds of meters. Therefore, these waterbodies are classified as lakes. At the study site these lakes occur ei- 

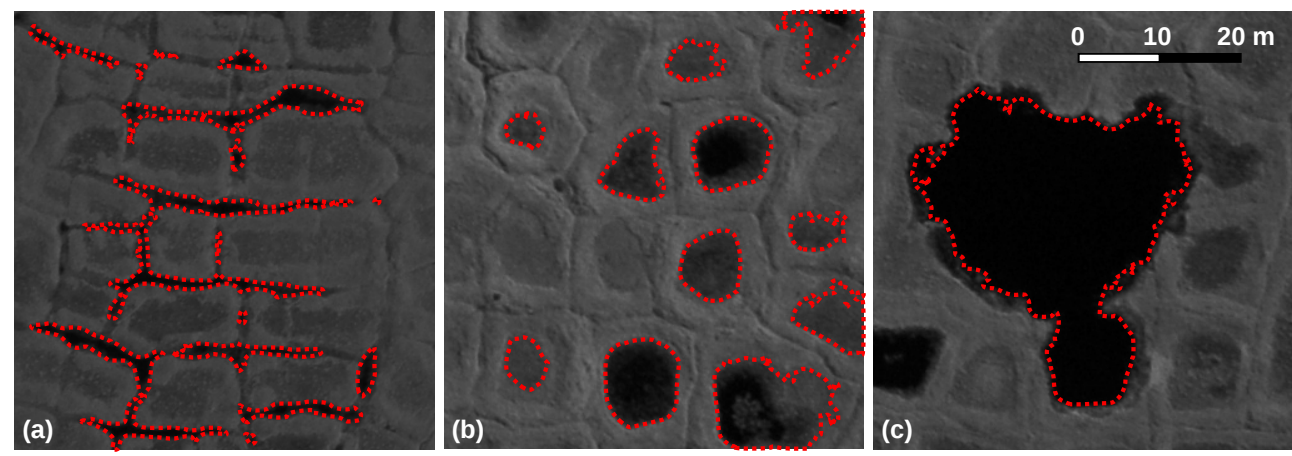

Figure 2. Typical ponds in the polygonal tundra mapped from near infrared (NIR) areal images. At the study site occur (a) ice-wedge ponds, (b) intra-polygonal ponds within intact polygonal structures, and (c) merged ponds show clear signs of degradation of the polygonal structures. According to their degree of degradation intra-polygonal ponds and ice-wedge ponds are classified as initial state ponds (ISPs) and merged ponds as advanced state ponds (ASPs).

ther in the form of oxbow lakes or thermokarst lakes which can be distinguished according to multiple geomorphological indicators such as shape and location. Oxbow lakes were excluded from this study. ISPs, ASPs, and thermokarst lakes can be part of an evolutionary process of permafrost degradation so that transitional forms between these waterbody types exist.

\subsection{Monitoring ice cover formation}

The process of ice cover formation was observed through three temperature profiles obtained from three different ponds. The temperatures were recorded using water temperature loggers (Onset, HOBO Pro v2 with an accuracy of better than $\pm 0.5^{\circ} \mathrm{C}$ ) positioned along a metal wire hanging down from a small buoy anchored in the middle of each pond. The first temperature profile was from an intra-polygonal pond, based on measurements from four temperature sensors. The first three temperature sensors were installed at depths of 0 , 0.15 , and $0.33 \mathrm{~m}$. The lowermost sensor was fixed directly on the ground at a depth of $0.4 \mathrm{~m}$. The pond was transitional between ISPs and ASPs in its level of degradation. Temperature profiles were also obtained for two typical ASPs, in each case using six temperature sensors over a depth of about $0.8 \mathrm{~m}$. In ASP1 the temperature sensors were deployed at depths of 0 , $0.20,0.35,0.53,0.67$, and $0.76 \mathrm{~m}$. In ASP2 the sensors were deployed at depths of $0,0.20,0.33,0.50,0.71$, and $0.75 \mathrm{~m}$. With exception of the lowermost sensors which were fixed to the ground, all sensors were held in place relative to the water surface by the floating buoy.

The ice cover thickness in each pond was inferred using the temperature records from the individual sensors. The date on which the freezing front crossed the temperature sensor was identified by a sudden drop in temperature after a relatively long period at a constant temperature of $0^{\circ} \mathrm{C}$.

\subsection{Sampling methane concentrations in lake ice}

Thirteen $\mathrm{CH}_{4}$ concentration profiles were obtained from ice blocks cut from eight waterbodies using a chainsaw (STIHL, Germany) with a $40 \mathrm{~cm}$ guide bar during a field program in April 2011. Three waterbodies were ponds with maximum water depths of less than $0.5 \mathrm{~m}$. The morphology of these ponds still placed them within the ISP category, despite some early signs of degradation. In the following, these ponds are named ISP1, ISP2, and ISP3. Four waterbodies had maximum depths greater than $0.5 \mathrm{~m}$ (up to $1.2 \mathrm{~m}$ ) and occurred within clearly degraded polygonal ground structures. The four ponds fell into the ASP category and are named ASP1 to ASP4 in the following. One of the sampled waterbodies fell into the category of a thermokarst lake with a maximum water depth of $5.3 \mathrm{~m}$. Temperature chains were installed in ISP1, ASP1, and ASP2 in order to observe ice cover growth (see Sect. 3.2). Despite the limited number of samples, the eight waterbodies provide a good cross-section of the different types of ponds and lakes at the study site.

The ice blocks were extracted by cutting ice columns to a depth of about $35 \mathrm{~cm}$, with surface dimensions of about $20 \mathrm{~cm}$ by $30 \mathrm{~cm}$, from the ice cover. A second ice column was then cut below the hole left by the first column in order to obtain ice profiles down to a maximum depth of about $70 \mathrm{~cm}$. The ice columns were cut into smaller cuboids with a base area of about $7 \times 7 \mathrm{~cm}$ and a height of $10 \mathrm{~cm}$. The cuboids were cleaned with a sharp and sterilized knife prior to transportation and analysis.

The ice samples were melted in $1 \mathrm{~L}$ plastic containers (Nalgene, USA), which were sealed with PTFE paste (Äronix, Germany). The impermeability of the containers to gas was verified by long-term testing using calibration gases prior to the analyses. The containers were flushed with nitrogen immediately after sealing in order to ensure zero $\mathrm{CH}_{4}$ concentration in the head space prior to melting. The head space volume in the containers varied between 0.3 and $0.6 \mathrm{~L}$ ac- 
cording to differences in sample volume. Possible corruption of the $\mathrm{CH}_{4}$ concentration measurements due to microbial activity during the melt procedure was tested using acidified $(10 \% \mathrm{HCl})$ parallel samples, but these showed no significant differences in $\mathrm{CH}_{4}$ concentration from the pure samples. Methane concentrations within the ice samples were determined by gas chromatography at the field station on Samoylov Island, using an Agilent GC 7890 gas chromatograph (Agilent Technologies, Germany) equipped with a Porapak Q column (1.8 m length, $2 \mathrm{~mm}$ ID) and a flame ionization detector (FID). Four repeat concentration measurements (five measurements in total) were performed in order to determine the measurement uncertainty.

The total $\mathrm{CH}_{4}$ content in the ice samples was evaluated by taking into account the head space concentration, sample volume, temperature, and pressure. A correction was also made for dissolved $\mathrm{CH}_{4}$ in the meltwater using Henry's law. These procedures introduced a wide range of potential error sources into the $\mathrm{CH}_{4}$ content measurements. Thus, the uncertainties in the total $\mathrm{CH}_{4}$ content were determined by Monte Carlo simulations assuming uniform uncertainty distributions for all parameters including measurement uncertainty, head space volume, sample volume, ambient temperature, and pressure (e.g., Anderson, 1976).

\subsection{Modeling methane concentrations in the ice cover of ponds}

The storage of methane in the ice cover of ponds was simulated using a simplified 1-D mass balance scheme, in an approach that closely resembles that used by Boereboom et al. (2012). The model was used to calculate net $\mathrm{CH}_{4}$ production rates during the freezing process by fitting the model to the $\mathrm{CH}_{4}$ concentration profiles obtained from the ice cover. The model simulated an ice cover growing downwards from the surface to the bottom of the pond, assuming a constant accumulation of bubbles from freeze-degassing of dissolved gases at the ice-water interface (see Appendix A). Ebullition bubbles were not taken into account in the model. Despite their importance as an efficient mode of $\mathrm{CH}_{4}$ emission from lakes, ebullition bubbles have small diameters relative to the lake surface area and they usually have a rare and heterogeneous distribution within a thermokarst pond, making them difficult to quantify from a limited number of small ice samples (Walter Anthony and Anthony, 2013). The heterogeneous distribution of ebullition bubbles also means that they are impossible to simulate using a simplified 1-D mass balance scheme. This limitation of the model means that the $\mathrm{CH}_{4}$ storage, and hence the production of $\mathrm{CH}_{4}$ in ponds, tends to be underestimated. The model results can therefore be considered to be conservative when calculating net $\mathrm{CH}_{4}$ production rates. Since the size of bubbles from freezedegassing depends largely on the rate of freezing (Carte, 1961), we assumed that the accumulation of freeze-out bub- bles was adequately represented by a constant rate during periods of constant freezing (Yoshimura et al., 2008).

The partial pressure of $\mathrm{CH}_{4}$ in the bubbles was assumed to be always in equilibrium with the partial pressure of $\mathrm{CH}_{4}$ in the water column, following Henry's law. The $\mathrm{CH}_{4}$ enrichment (net $\mathrm{CH}_{4}$ production) is controlled by $\mathrm{CH}_{4}$ production and oxidation. Very stable temperature conditions with slowly decreasing temperatures from about 2 to $0^{\circ} \mathrm{C}$ were observed at the bottom of shallow ponds and lakes during the freezing period from October through February at the study site (Boike et al., 2013). Assuming a standard $Q_{10}$ relationship between $\mathrm{CH}_{4}$ production and temperature $\left(Q_{10}=3\right)$, a maximum change in net $\mathrm{CH}_{4}$ production of about a factor of 1.3 can be expected (van Hulzen et al., 1999). Thus, we assumed constant $\mathrm{CH}_{4}$ production and oxidation rates during the freezing period. Furthermore, other factors controlling $\mathrm{CH}_{4}$ production such as sediment composition are assumed to remain constant during the freezing period. We also assumed a uniform enrichment of methane in the water column beneath the ice cover. A uniform distribution of dissolved $\mathrm{CH}_{4}$ in the shrinking water column is considered a reasonable guess for the investigated very shallow waterbodies although concentration gradients are reported for deeper lakes. However, increased $\mathrm{CH}_{4}$ concentrations at the bottom of the ponds would lead to underestimated net $\mathrm{CH}_{4}$ production in the model calculations. As well as the stable temperature conditions, the model also assumed constant pressure conditions during the freezing process. Nevertheless, air pressure changes are an important factor for bubble formation in lakes and can result in layers of dense bubbles in the ice cover (Walter Anthony et al., 2010). Thus, the obtained ice profiles were analyzed for occurrence of bubble layers that were related to air pressure changes before they were used for modeling. The storage of bubbles in the ice cover was simulated by integrating an effective bubble crosssection and $\mathrm{CH}_{4}$ concentration over the current ice cover thickness. The effective bubble cross-section was calculated as a horizontal area occupied by bubbles of an infinitesimally thin horizontal ice cover slices with an area of $1 \mathrm{~m}^{2}$. The bubble volume stored in the ice cover was assumed to be no longer in gaseous exchange with the unfrozen waterbody. When the maximum solubility of methane in the shrinking water column was reached, the model assumed that the excess methane was stored directly in the ice cover. The storage of excess $\mathrm{CH}_{4}$ resulted in a marked increase in the methane concentration within the ice cover.

The mass balance scheme results in a first-order ordinary differential equation, which can be solved analytically (see Appendix A). In general, the model outcome is determined by the net $\mathrm{CH}_{4}$ production rate, the effective bubble crosssection, the ice cover growth rate, and the pond depth. The pond depth and the ice cover growth rate are measured and hence known for all sites, and the net $\mathrm{CH}_{4}$ production rate and effective bubble cross-section can be inferred by fitting the model to measured $\mathrm{CH}_{4}$ concentration profiles. Previous 
measurements within the study area have shown that the concentration of dissolved $\mathrm{CH}_{4}$ in different ponds varies widely (between $6 \times 10^{-9}$ and $2 \times 10^{-5} \mathrm{~mol} \mathrm{~m}^{-3}$ ) prior to the onset of freezing (Abnizova et al., 2012). The sensitivity of the fitting procedure was therefore tested over the entire range of initial $\mathrm{CH}_{4}$ concentrations. The model was fitted to the measured $\mathrm{CH}_{4}$ profiles from the ice samples using a nonlinear fitting routine provided by MATLAB. This fitting procedure included evaluation of the $95 \%$ confidence intervals on the fitted parameters and the model output.

\section{Results}

\subsection{Waterbody distribution and ice cover formation}

Almost $15 \%$ of the study area (SA) consists of waterbodies, of which about $60 \%$ are less than $300 \mathrm{~m}^{2}$ in surface area (Fig. 3a). In the sub-areas SUB I and SUB II the pond surface areas range between 0 and $300 \mathrm{~m}^{2}$ and the maximum water depth ranges between 0 and $1.5 \mathrm{~m}$. About $10 \%$ of the tundra landscapes in SUB I and SUB II are occupied by ponds that are shallower than $0.2 \mathrm{~m}$. Most of these shallow ponds fall into the ISP class, with little or no sign of degradation in the surrounding polygon rims. Ponds with water depths of 0.5 to $0.6 \mathrm{~m}$ and 0.8 to $1.0 \mathrm{~m}$ were found to be slightly more abundant than ponds with water depths of 0.2 to $0.4 \mathrm{~m}$ and 1.0 to $1.3 \mathrm{~m}$ (Fig. 3b). Most of the ponds with a water depth greater than $0.5 \mathrm{~m}$ belonged to the ASP class, which made up the largest proportion of ponds in the entire study area. Despite the wide range of water depths in the surveyed ponds, the deeper ponds tended to be larger than the shallower ones which coincided with increased thaw depths beneath the deeper ponds. This tendency was especially pronounced for ponds with depths greater than $0.5 \mathrm{~m}$. In contrast, ISPs with water depths of less than $0.5 \mathrm{~m}$ did not show any clear depth-size correlation. The size of the ISPs appeared to be mainly determined by the size of the polygonal structures.

Ice cover growth (freezing) rates were investigated in three different ponds during the winters of 2010-2011 and 20112012. The freezing rate detection was limited to the first part of winter since temperature profile measurements were only available to a maximum depth of about $0.8 \mathrm{~m}$ (see Sect. 3.2). During the winter of 2010-2011 the average growth rate of the ice cover was $0.91 \pm 0.11 \mathrm{~cm} \mathrm{day}^{-1}$ (Fig. 4a). The three investigated ponds showed deviations from the linear average of up to $0.15 \mathrm{~m}$, which were particularly evident from the beginning of October to the middle of November. The shallowest pond (ISP1) revealed the highest freezing rate and was completely frozen (to the bottom: a depth of about $0.4 \mathrm{~m}$ ) by the beginning of November. The other ponds (ASP1 and ASP2) achieved a similar ice cover thickness about 3 weeks later. In contrast to the winter of 2010-2011, all investigated ponds showed a very consistent rate of ice cover formation during the winter of 2011-2012 (Fig. 4b), when the average growth rate of the ice cover was $1.24 \pm 0.12 \mathrm{~cm} \mathrm{day}^{-1}$ with only minor deviations from the linear average (up to about $0.05 \mathrm{~m}$, which is well within the assumed measurement uncertainty). Despite the linear character of the freezing process, the measurements showed some temporal variations in the freezing rate. During both winter periods pond ISP1 showed a very linear freezing behavior but, in contrast, the deeper ponds showed a lower rate of freezing at the beginning of the freezing period, a slightly increased rate in the middle of the period, and a lower rate again when the ice cover approached the bottom of the ponds.

\subsection{Distribution of gas bubbles within the ice cover}

Most of the ice columns were very clear with only a few visible bubbles. After a short warm event during the field campaign a very thin layer of white ice (1-3 cm layer thickness) was observed above black ice at some locations. This white ice layer was excluded from further analysis. The ice columns from the ISP1 and ISP2 ponds showed a layer of abundant bubbles close to the bottom of the ponds, starting from a depth of about $15 \mathrm{~cm}$. Moss stems in the sediments on the floor of these two ponds were usually completely surrounded by bubbles. The diameter of these bubbles ranged from about $1 \mathrm{~mm}$ to $5 \mathrm{~mm}$. Ice samples containing these dense and often interconnected bubbles along moss stems were excluded from the $\mathrm{CH}_{4}$ concentration measurements.

In addition, two or three thin layers of bubbles were observed in ISP1 and ISP2 at depths of between 5 and $15 \mathrm{~cm}$. Three very thin layers of bubbles were also observed at similar depths (between 5 and $15 \mathrm{~cm}$ ) in the ice columns from pond ISP3. The consistent occurrence of these thin bubble layers in similar depths and different ponds indicates a formation related to air pressure changes. The three ISPs feature similar water depths of 30 to $45 \mathrm{~cm}$ and we expect similar freezing rates. However, the sizes of these bubbles layers were assessed to be negligible compared to the ice sample sizes so that they were not excluded from the $\mathrm{CH}_{4}$ concentration measurements. The ice columns from the relatively deep ponds (ASP1, ASP2, and ASP3), which had depths greater than $0.5 \mathrm{~m}$, did not reach the bottom of the ponds and hence the presence or absence of a layer of abundant bubbles close to the bottom of the ponds (as seen in the shallow ISP1 and ISP2 ponds) could not be verified. The ice columns from pond ASP3 revealed a narrow bubble layer at about $15 \mathrm{~cm}$ depth similar to that seen in the shallow ponds, but those from ponds ASP1 and ASP2 showed no visible bubbles between the surface and a depth of $35 \mathrm{~cm}$. However, all ice columns from the deep ponds were consistent in showing two to three thin bubble layers between the depths of 35 and $40 \mathrm{~cm}$. 

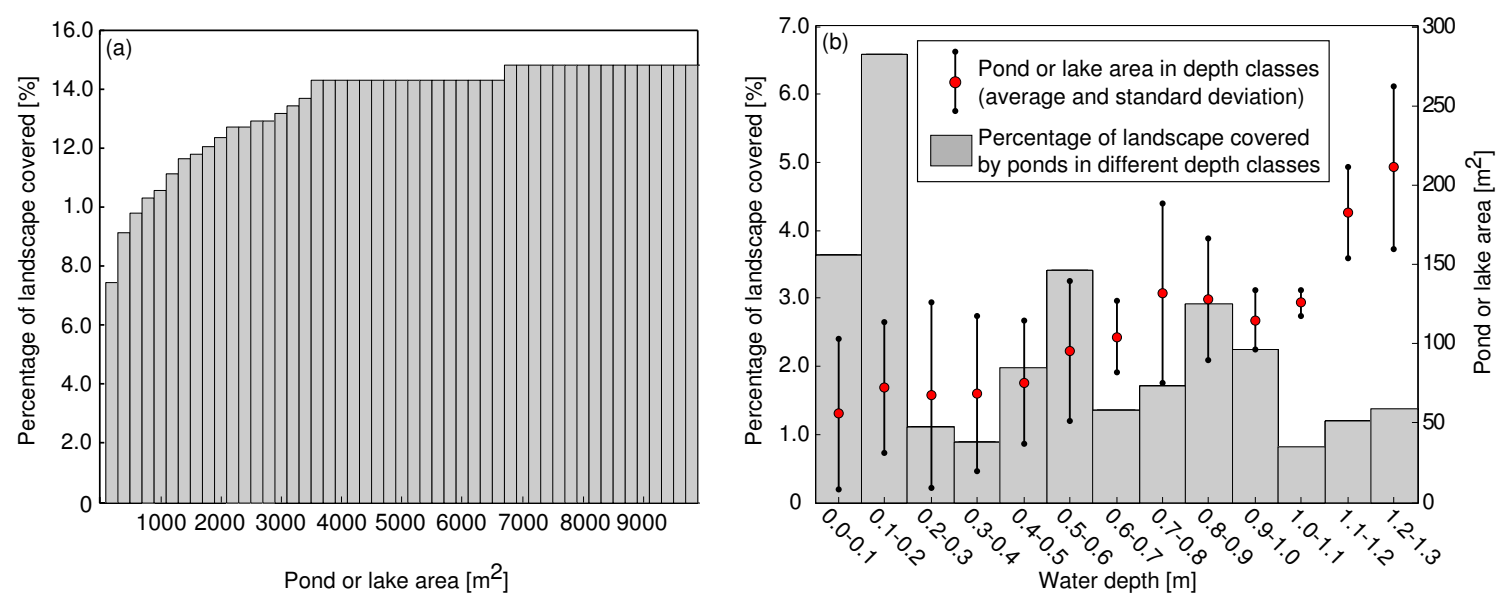

Figure 3. Cumulative percentage of landscape covered by ponds in different size classes (a). Percentage of landscape covered by ponds in different depth classes (b). The secondary $y$ axis in (b) shows the average surface area for each depth class. The whiskers indicate the standard deviation for each depth class.
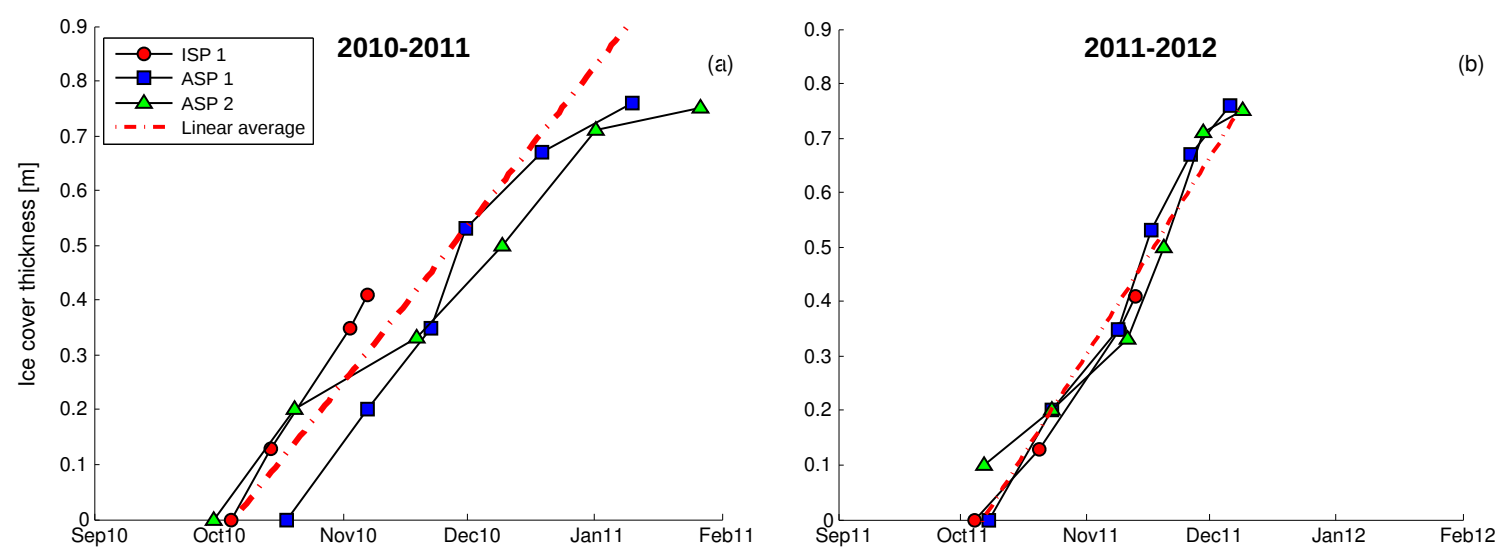

Figure 4. Growth of ice cover inferred from water temperature measurements in three different ponds during (a) the winter of 2010-2011, and (b) the winter of 2011-2012.

\subsection{Methane concentrations in lake and pond ice}

The $\mathrm{CH}_{4}$ concentrations obtained from all ice samples are shown in Fig. 5, where they are plotted semi-logarithmically against the ratio of sample depth to maximum water depth. The whiskers following the orientation of the depth axis indicate the sample size while the whiskers following the orientation of the concentration axis indicate uncertainties in the measured $\mathrm{CH}_{4}$ concentrations according to the Monte Carlo simulations (see Sect. 3.3). In addition, the samples are color coded according to the surface area of the lake or pond from which they were obtained. The $\mathrm{CH}_{4}$ concentration within the ice cover showed considerable variation, ranging from the detection limit of the gas analyzer up to $0.08 \mathrm{~mol} \mathrm{~m}^{-3}$. The detection limit of the used GC setup was at about $1 \mathrm{ppm}$ which would equate to about $2 \times 10^{-5} \mathrm{~mol} \mathrm{~m}^{-3}$ for $\mathrm{CH}_{4}$ concentrations in ice samples assuming a head space volume of about $0.5 \mathrm{~L}$. On average about $2 \times 10^{-3} \mathrm{~mol} \mathrm{~m}^{-3}$ $\left(0.03 \mathrm{~g}_{\mathrm{CH}_{4}} \mathrm{~m}^{-3}\right)$ was stored in the ice cover between the surface and a depth of $0.65 \mathrm{~m}$. However, these concentrations varied over 2 orders of magnitude indicating marked differences between the different waterbody types. The $\mathrm{CH}_{4}$ concentration was generally observed to increase with depth. The highest $\mathrm{CH}_{4}$ concentrations were recorded from waterbodies with surface areas of less than $50 \mathrm{~m}^{2}$ and in ice samples from close to the bottom of waterbodies. The results suggest an exponential relationship between $\mathrm{CH}_{4}$ concentration and ice cover thickness; the measured concentrations generally followed an exponential trend, with the exception of four outliers. A detailed analysis of individual $\mathrm{CH}_{4}$ profiles confirmed the exponential increase in $\mathrm{CH}_{4}$ concentrations with depth and the marked differences between waterbodies (see Fig. 6). An exponential increase in $\mathrm{CH}_{4}$ concentration was recorded for all ponds in which the acquired ice columns reached close (about $30 \mathrm{~cm}$ ) to the bottom of the waterbody. The lowest $\mathrm{CH}_{4}$ concentrations were recorded in 


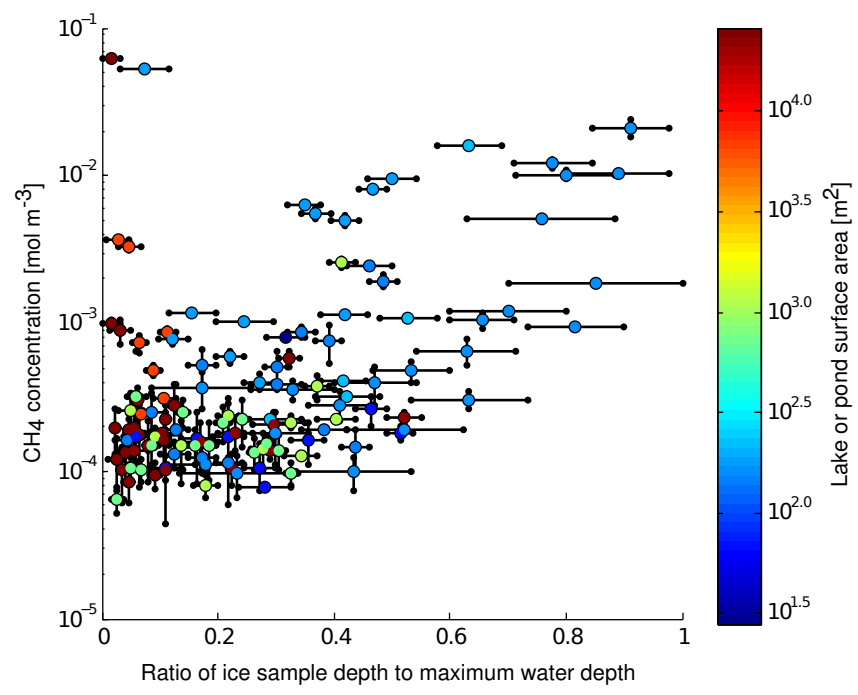

Figure 5. Methane concentrations within the ice cover of different lakes and ponds, plotted against the ratio of sample depth to maximum water depth (note the logarithmic scale). The circles representing individual samples are colored according to the surface area of the lake or pond from which they came.

the ice columns from large thermokarst lakes. In these lakes, only the uppermost part of the ice cover was sampled relative to the maximum lake depths. Two of the four outliers that do not fit into the general exponential behavior revealed very high $\mathrm{CH}_{4}$ concentrations of up to $0.08 \mathrm{~mol} \mathrm{~m}^{-3}$ (Fig. 5). The other two outliers only showed moderately increased concentrations of about $0.003 \mathrm{~mol} \mathrm{~m}^{-3}$. All outliers were found relatively close to the top of the ice cover and three of four outliers were observed at thermokarst lakes with surface areas larger than $10^{4} \mathrm{~m}^{2}$.

\subsection{Modeling methane storage in the ice cover}

The maximum $\mathrm{CH}_{4}$ concentrations measured in the ISP1, ISP3, and ASP3 samples were about 1 order of magnitude higher than those from ISP2, ASP1, ASP2, and ASP4 (Fig. 6). The ice samples were typically 5 to $10 \mathrm{~cm}$ high, which placed a limit on the depth resolution, but this was improved to some extent by overlap between samples. The uncertainty in the $\mathrm{CH}_{4}$ concentration from each sample was relatively low although some differences were observed between overlapping samples, especially in those from the ASP1 and ASP2 ponds. Despite these uncertainties and the limited depth resolution, all ponds consistently revealed an exponential increase in $\mathrm{CH}_{4}$ concentration with depth (Fig. 6). The ASP3 profile in particular showed a very sharp increase in concentration in the deepest sample. The increase in $\mathrm{CH}_{4}$ concentrations in the ISP1 and ISP2 coincided with increased bubble densities, but no general relationship was observed between bubble density and $\mathrm{CH}_{4}$ concentration in the ISP3, ASP1, ASP2, and ASP3 ponds.
The derived $\mathrm{CH}_{4}$ concentration profiles for six of the ponds were analyzed and the mass balance model was fitted to these profiles in order to estimate net $\mathrm{CH}_{4}$ production rates (see. Sect. 3.4). From this fitting procedure, the effective bubble cross-sections and net $\mathrm{CH}_{4}$ production rates were obtained for all the analyzed ponds and also for an additional ASP (ASP4). The model was able to reproduce the observed $\mathrm{CH}_{4}$ concentration profiles for all of the ponds. The best fit results and the $95 \%$ confidence intervals of the fitting procedure are shown in Fig. 6. Most of the differences between the best fit and the actual measurements fall within the $95 \%$ confidence interval of the model output, taking into account the depth resolution and the uncertainties in the measured $\mathrm{CH}_{4}$ concentrations. The model also successfully reproduced the sharp increase in $\mathrm{CH}_{4}$ concentration noted in the ASP3 profile. In this particular case, the model simulated the storage of excess $\mathrm{CH}_{4}$ in the ice cover, since the maximum solubility of $\mathrm{CH}_{4}$ in water (about $2.5 \mathrm{~mol} \mathrm{~m}^{-3}$ at about $0^{\circ} \mathrm{C}$ and $1000 \mathrm{hPa}$ ) was reached in the shrinking water column.

The inferred net $\mathrm{CH}_{4}$ production rates resulting from the fitting procedure revealed marked variations in net $\mathrm{CH}_{4}$ production between the different waterbodies (Fig. 7). The net production rates ranged from $10^{-11}$ to $10^{-7} \mathrm{~mol} \mathrm{~m}^{-2} \mathrm{~s}^{-1}$ (0.01 to $140 \mathrm{mg}_{\mathrm{CH}_{4}} \mathrm{~m}^{-2} \mathrm{day}^{-1}$ ), and the effective bubble cross-sections ranged from $10^{-4} \mathrm{~m}$ to $10^{-2} \mathrm{~m}$. The net $\mathrm{CH}_{4}$ production rate was generally higher in profiles with smaller effective bubble cross-sections. The highest net $\mathrm{CH}_{4}$ production rates were calculated for the ASP1, ASP2, ASP3, and ASP4 which had maximum water depths greater than $0.5 \mathrm{~m}$ and showed clear signs of recent permafrost degradation. In contrast, lower net $\mathrm{CH}_{4}$ production rates but larger bubble cross-sections were calculated for the ISP1, ISP2, and ISP3.

\section{Discussion}

\subsection{Characteristics and sensitivities of Arctic ponds}

The survey of ponds and lakes within the study area clearly showed an abundance of ponds in the lowland tundra landscape of the Lena River delta. Almost $10 \%$ of the total land surface was occupied by waterbodies with surface areas of less than $300 \mathrm{~m}^{2}$, most of which were no deeper than $1 \mathrm{~m}$. The abundance of small waterbodies in the Arctic has been noted in a number of previous studies (Emmerton et al., 2007; Grosse et al., 2008).

Furthermore, this study has demonstrated that the freezing rates of ponds can vary greatly from one pond to another, and from one year to another. Ice thicknesses measurements from two consecutive years revealed a difference in ice cover thickness of about $40 \%$. Detailed investigations of the surface energy balance within the study area have suggested that marked interannual differences in the freezing rate can be largely attributed to differences in the snow cover and the wintertime cloud cover (Langer et al., 2011b). 

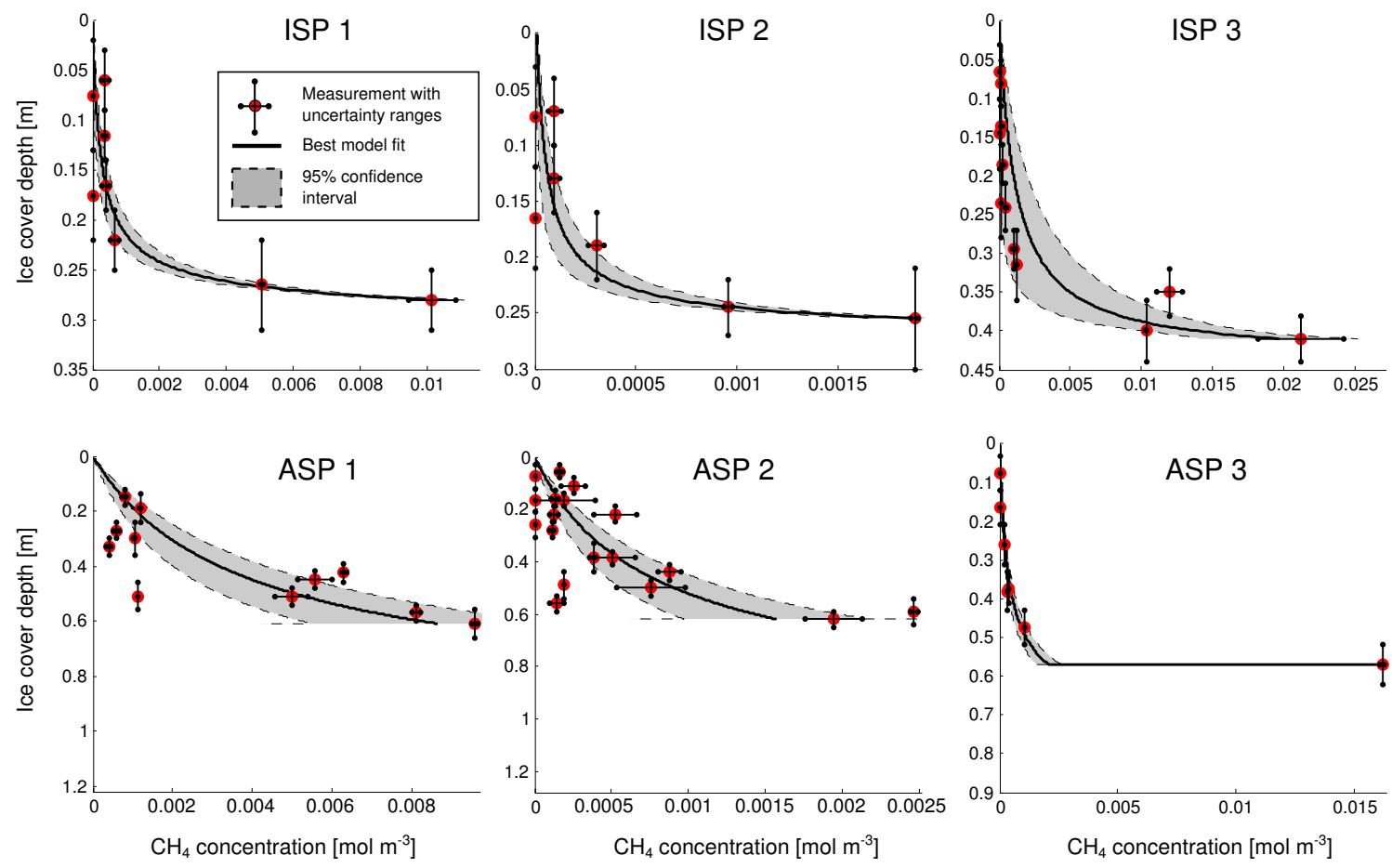

Figure 6. Measured and modeled $\mathrm{CH}_{4}$ concentrations with ice cover depth of different ponds. The whiskers show the measurement uncertainty and the shaded areas indicate the $95 \%$ confidence interval of the model. The range of depth axis represents the maximum pond depth. Sampling was limited to a maximum ice cover depth of about $60 \mathrm{~cm}$ due to the length of the guide bar used with the chainsaw.

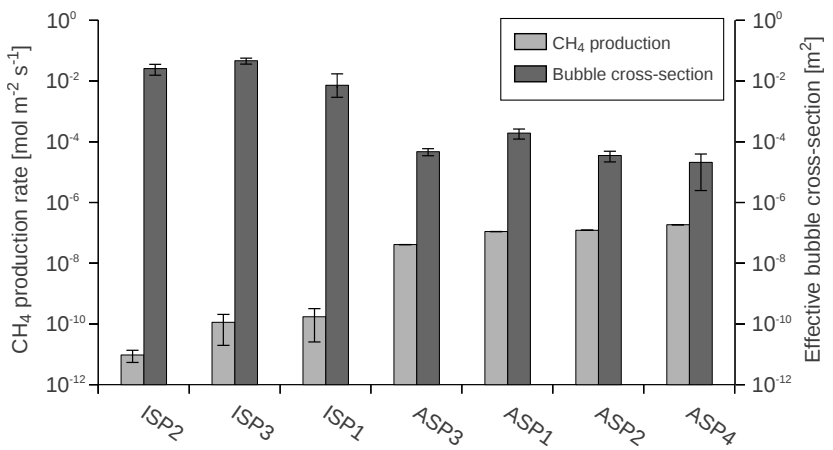

Figure 7. Net methane production and effective bubble crosssection for different ponds, calculated by inverse modeling using the 1-D mass balance model (note the logarithmic scale). The whiskers indicate the $95 \%$ confidence interval of the model results.

The survey of waterbodies also revealed that a large fraction of ponds are no deeper than $20 \mathrm{~cm}$. These shallow ponds occur mainly in low-centered polygons with little or no signs of degradation. The occurrence and size of such ponds is assumed to be directly related to the polygonal microtopography, which also explains why no relationship could be observed between pond size and water depth. There is a clear contrast with the frequency of ponds deeper than $0.5 \mathrm{~m}$. These ponds show a more uniform depth distribution with a slight maximum between 0.5 and $1 \mathrm{~m}$. A depth-size relation- ship was observed for these deeper ponds. The existence of such a relationship suggests a link between the erosive processes leading to the deepening of the pond and the size of the waterbody. However, the poorly defined depth-size relationships indicates a rather complex interrelationship.

\section{2 $\mathrm{CH}_{4}$ concentrations and net production rates}

All of the $\mathrm{CH}_{4}$ profiles derived from ice samples indicate an exponential increase in $\mathrm{CH}_{4}$ concentration with depth, which is in agreement with previous observations by Phelps et al. (1998) from various Alaskan and Canadian lakes. The consistency between these two studies suggests that both freezedegassing of $\mathrm{CH}_{4}$ and $\mathrm{CH}_{4}$ storage within the ice cover generally occurs in shallow lakes. Some individual concentrations have been observed to deviate from the general exponential behavior. These outliers may be explained by the admixture of ebullition bubbles, which are not explicitly accounted for in this study. However, the exponential relationship between ice depth and $\mathrm{CH}_{4}$ concentration can be reproduced by a simplified mass balance model, assuming constant net $\mathrm{CH}_{4}$ production and bubble accumulation. The exponential shape results from the dynamic balance between net $\mathrm{CH}_{4}$ production, freeze-degassing, and storage of $\mathrm{CH}_{4}$ within the ice cover.

The mass balance model was successfully fitted to the measured $\mathrm{CH}_{4}$ concentrations by optimizing the net $\mathrm{CH}_{4}$ 
production rate and the effective bubble size. A high level of confidence was achieved in all profiles. Furthermore, the model was able to realistically reproduce the sharp increase in $\mathrm{CH}_{4}$ concentration observed in one of the profiles. This indicated that the model was able to accurately represent the timing of $\mathrm{CH}_{4}$ saturation in the shrinking water column during freezing. The overall high level of performance of the model for the different profiles suggests that the basic process of $\mathrm{CH}_{4}$ freeze-degassing and storage in the ice cover is adequately represented. In addition, sensitivity tests revealed that the fit was very robust against variations in the initial values of net $\mathrm{CH}_{4}$ production and effective bubble size. This inspires confidence that the magnitudes of the fitted net $\mathrm{CH}_{4}$ production and bubble accumulation rates are realistic. The results were also found to be very robust against uncertainties in the initial $\mathrm{CH}_{4}$ concentration within the water column, prior to the onset of freezing. Except for the ponds ISP2 and ASP2, sensitivity tests over the entire range of possible initial $\mathrm{CH}_{4}$ concentrations $\left(1 \times 10^{-9}\right.$ and $1 \times 10^{-5} \mathrm{~mol} \mathrm{~m}^{-3}$, see Sect. 3.4) were not found to affected the modeled magnitudes of $\mathrm{CH}_{4}$ production and effective bubble cross-section. For the ponds ISP2 and ASP2 the model produced consistent results with initial $\mathrm{CH}_{4}$ concentrations ranging between $1 \times 10^{-9}$ and $1 \times 10^{-7} \mathrm{~mol} \mathrm{~m}^{-3}$. This limited range relates to the generally very low $\mathrm{CH}_{4}$ concentrations found in these ponds. Higher initial $\mathrm{CH}_{4}$ concentrations would require methane decomposition instead of production to reproduce the observed $\mathrm{CH}_{4}$ concentration profiles. Despite the robustness of the model, unpredictable errors due to gas loss from the edges of the samples or methane oxidation within the ice could negatively bias the measured concentration rates, and consequently the resulting net $\mathrm{CH}_{4}$ production rates. Oversimplified model assumptions, such as uniformly distributed $\mathrm{CH}_{4}$ concentrations and a constant rate of bubble accumulation, could also affect the simulated net $\mathrm{CH}_{4}$ production rates. The model results must therefore be considered to represent first-order estimates. The results of the fitting procedure generally suggest marked differences in the net $\mathrm{CH}_{4}$ production from different pond types. Initial state ponds (water depth $<0.5 \mathrm{~m}$ ) show very low net production rates, of the order of $10^{-11}$ and $10^{-10} \mathrm{~mol} \mathrm{~m}^{-2} \mathrm{~s}^{-1}$ (0.01 to $0.14 \mathrm{mg}_{\mathrm{CH}_{4}} \mathrm{~m}^{-2} \mathrm{day}^{-1}$ ). In contrast, advanced state ponds (depth $>0.5 \mathrm{~m}$ ) with clear signs of thermal erosion show net $\mathrm{CH}_{4}$ production rates of the order of $10^{-7} \mathrm{~mol} \mathrm{~m}^{-2} \mathrm{~s}^{-1}$ $\left(140 \mathrm{mg}_{\mathrm{CH}_{4}} \mathrm{~m}^{-2} \mathrm{day}^{-1}\right)$. Similar ranges of $\mathrm{CH}_{4}$ emission rates have previously been reported in summer from ponds in a similar type of landscape on Bylot Island, Canada (Laurion et al., 2010). The net $\mathrm{CH}_{4}$ production rates from the ponds in our study area were of a similar magnitude to observed summertime $\mathrm{CH}_{4}$ emission rates (excluding ebullition) from ice-wedge ponds on Bylot Island. In addition, the results of this study provide further evidence that the marked differences in net $\mathrm{CH}_{4}$ production rates between the different pond types are likely to be due to fundamental differences in biogeochemical processes resulting from active thermal erosion which increases the availability of organic material (Laurion et al., 2010; Laurion and Mladenov, 2013).

The differences in net $\mathrm{CH}_{4}$ production may also be related to differences in the vegetation such as Scorpidium scorpioides growing on the bottom of ponds. These mosses live in symbiosis with $\mathrm{CH}_{4}$-oxidizing bacteria that could effectively limit $\mathrm{CH}_{4}$ emission (Liebner et al., 2011). Photosynthesis and oxygen production are still possible beneath the growing ice cover during early winter. Indicators of active photosynthesis in ISPs during freezing is provided by the large number of bubbles observed around moss stems. However, other processes such as $\mathrm{CO}_{2}$ emission through moss respiration or preferential bubble nucleation at the moss stems could have contribute to the formation of these bubble clusters. Since it was likely that the ice samples from these highly porous layers have lost their original gas content during sampling, they were excluded from the $\mathrm{CH}_{4}$ concentration measurements. Thus, the impact of mosses on the net $\mathrm{CH}_{4}$ production and storage in the ice cover remains unclear.

The maximum summertime $\mathrm{CH}_{4}$ emission rates per square meter from the average tundra landscape on Samoylov Island are of the order of $5 \times 10^{-8} \mathrm{~mol} \mathrm{~m}^{-2} \mathrm{~s}^{-1}$ $\left(60 \mathrm{mg}_{\mathrm{CH}_{4}} \mathrm{~m}^{-2}\right.$ day ${ }^{-1}$ Sachs et al., 2008; Wille et al., 2008). These average landscape $\mathrm{CH}_{4}$ emission rates were obtained by eddy covariance measurements with typical footprint areas of several hundreds of square meters including ponds and vegetated tundra soils. Thus, these measurements are not directly comparable to the production rates of individual ponds inferred by this study. Nevertheless, the eddy covariance measurements provide a reference value which allows one to asses the strength of $\mathrm{CH}_{4}$ production in ponds relative to a landscape-scale $\mathrm{CH}_{4}$ emission rate. Under this consideration, the early winter net $\mathrm{CH}_{4}$ production rates per square meter from ASPs are about 5 times larger than the maximum summertime landscape-scale $\mathrm{CH}_{4}$ emissions per square meter. Considering that ponds occupy about $10 \%$ of the tundra landscape, this stresses the importance of ponds and the freezing period to the local carbon cycle. Even during the freezing period, small waterbodies can be hotspots of $\mathrm{CH}_{4}$ production in tundra landscapes. It is, however, important to note that our results do not take into account $\mathrm{CH}_{4}$ that is transported and stored in the ice cover through ebullition, and the total $\mathrm{CH}_{4}$ production from ASPs is therefore likely to be much greater than our modeling suggests.

\section{Conclusions}

Our results show that ponds in the polygonal tundra can be important sources of $\mathrm{CH}_{4}$ during the freezing period. Extensive measurements in the ice cover of different ponds have revealed that the $\mathrm{CH}_{4}$ concentrations increase exponentially with depth, indicating intensive $\mathrm{CH}_{4}$ production under the growing ice cover. The measured $\mathrm{CH}_{4}$ concentration profiles were successfully reproduced by 1-D mass balance 
model demonstrating that the exponential shape results from the dynamic balance between net $\mathrm{CH}_{4}$ production, freezedegassing, and storage of $\mathrm{CH}_{4}$ within the ice cover. Furthermore, inverse modeling has revealed high net $\mathrm{CH}_{4}$ production rates in ponds showing signs of erosion in the surrounding polygonal ground structures, which contrasts with the low net production rates observed in ponds located within almost intact polygonal ground structures. These results have far-ranging implications for the $\mathrm{CH}_{4}$ emission potential of lowland tundra landscapes, since
- The $\mathrm{CH}_{4}$ that is produced during the freezing period is likely to be released into the atmosphere during the spring melt.

- Ponds are abundant in lowland tundra landscapes and their occurrence is closely related to the state of degradation of surface structures in permafrost landscapes. Hence, further degradation of surface structures due to thawing permafrost may affect the occurrence of ponds and thus the $\mathrm{CH}_{4}$ emissions from tundra landscapes.

- The net production of $\mathrm{CH}_{4}$ from ponds that show signs of erosion in the surrounding polygonal ground structures is observed to be 2 to 3 orders of magnitude greater than from ponds located within largely intact permafrost. Any future warming-induced erosion and pond expansion may therefore greatly increase the $\mathrm{CH}_{4}$ emission potential of tundra landscapes. 


\section{Appendix A}

The mass balance of methane in a freezing pond can be written as

$N_{\mathrm{i}}+N_{\mathrm{g}}+N_{\mathrm{a}}-N_{0}-N_{\mathrm{P}}=0$,

where $N_{\mathrm{i}}$ is the amount of $\mathrm{CH}_{4}$ molecules that are stored in the ice cover, $N_{\mathrm{g}}$ is the amount of methane stored in bubbles at the ice-water interface, $N_{\mathrm{a}}$ is the number of dissolved methane molecules in the water column, $N_{0}$ is the amount of dissolved methane that is stored in the water column at the start of freezing, and $N_{\mathrm{P}}$ is the number of $\mathrm{CH}_{4}$ molecules produced. The individual $\mathrm{CH}_{4}$ components of the mass balance are parameterized as

$N_{\mathrm{i}}=A_{\mathrm{b}} \int_{0}^{t} C(\tau) \frac{\partial \mathrm{z}(\tau)}{\partial \tau} \mathrm{d} \tau$,

$N_{\mathrm{g}}=C(t) V_{\mathrm{b}}$,

$N_{\mathrm{a}}=C(t) k_{\mathrm{H}} R T_{\mathrm{w}}\left(\mathrm{z}_{0}-\mathrm{z}(t)\right)$,

$N_{0}=C_{0} z_{0}$,

$N_{\mathrm{P}}=\int_{0}^{t} P(\tau) d \tau$,

where $v$ is the concentration of methane in bubbles at the ice-water interface at time $t ; k_{\mathrm{H}}$ is the Henry's law constant of methane, assuming constant pressure and a water temperature $T_{\mathrm{w}}$ of $273.15 \mathrm{~K} ; R$ is the universal gas constant; $A_{\mathrm{b}}$ is the effective bubble size in direct contact with the ice-water interface; $z(t)$ is the ice cover thickness; $V_{\mathrm{b}}$ is the effective volume of bubbles at the ice-water interface; $z_{0}$ is the depth of the water column at the start of freezing; $C_{0}$ is the concentration of methane in water at the start of freezing; and $P$ is the rate of net methane production in the pond. Eq. (A4) is modified to

$N_{\mathrm{a}}=k_{\mathrm{H}}\left(z_{0}-z(t)\right)$ as soon as $\mathrm{CH}_{4}$ saturation is reached in the remaining water column so that all excess methane is deposited directly into the ice cover. Thus, combining Eqs. (A1-A7) results in two first-order linear differential equations for (i) the duration of $\mathrm{CH}_{4}$ undersaturation $\left(t \leq t_{\mathrm{S}}\right)$ and (ii) the period of $\mathrm{CH}_{4}$ saturation $\left(t>t_{\mathrm{S}}\right)$

$$
\begin{array}{ll}
a C(t)+b \frac{\partial C(t)}{\partial t}-P(t)=0, & \text { for } 0 \leq t \leq t_{\mathrm{S}} \\
c C(t)+d \frac{\partial C(t)}{\partial t}-e-P(t)=0, & \text { for } t>t_{\mathrm{S}}
\end{array},
$$

where $a, b, c, d$, and $e$ summarize the parameters according to Eq. A2-A7. The differential equations can be solved with exponential functions so that the concentration of methane in the water column and in the ice cover can be calculated for each time step in the freezing process. 
Acknowledgements. Special thanks go to Katrin Fröb and Karoline Morling for their invaluable work in the field and laboratory. Furthermore, we thank Waldemar Schneider and our Russian partners at AARI and the Lena Delta Reserve for the logistical support of our field work. We gratefully acknowledge the financial support by the Helmholtz Association through a grant (VH-NG 203) awarded to Julia Boike. Furthermore, the authors acknowledge the financial support by the European Union FP7-ENV project PAGE21 under contract number GA282700. We would also like to thank the two anonymous reviewers for the very constructive comments which helped to improve our manuscript. Moreover, we would like to thank the associate editor Isabelle Laurion for very helpful comments and suggestions.

Edited by: I. Laurion

\section{References}

Abnizova, A., Siemens, J., Langer, M., and Boike, J.: Small ponds with major impact: The relevance of ponds and lakes in permafrost landscapes to carbon dioxide emissions, Global Biogeochem. Cy., 26, GB2041, doi:10.1029/2011GB004237, 2012.

Anderson, G.: Error propagation by the Monte Carlo method in geochemical calculations, Geochim. Cosmochim. Ac., 40, 15331538, doi:10.1016/0016-7037(76)90092-2, 1976.

Boereboom, T., Depoorter, M., Coppens, S., and Tison, J.-L.: Gas properties of winter lake ice in Northern Sweden: implication for carbon gas release, Biogeosciences, 9, 827-838, doi:10.5194/bg9-827-2012, 2012.

Boike, J., Langer, M., Lantuit, H., Muster, S., Roth, K., Sachs, T., Overduin, P., Westermann, S., and McGuire, A.: Permafrost Physical Aspects, Carbon Cycling, Databases and Uncertainties, 159-185, Springer Netherlands, doi:10.1007/978-94-007-41591_8, 2012.

Boike, J., Kattenstroth, B., Abramova, K., Bornemann, N., Chetverova, A., Fedorova, I., Fröb, K., Grigoriev, M., Grüber, M., Kutzbach, L., Langer, M., Minke, M., Muster, S., Piel, K., Pfeiffer, E.-M., Stoof, G., Westermann, S., Wischnewski, K., Wille, C., and Hubberten, H.-W.: Baseline characteristics of climate, permafrost and land cover from a new permafrost observatory in the Lena River Delta, Siberia (1998-2011), Biogeosciences, 10, 2105-2128, doi:10.5194/bg-10-2105-2013, 2013.

Brosius, L. S., Walter Anthony, K. M., Grosse, G., Chanton, J. P., Farquharson, L. M., Overduin, P. P., and Meyer, H.: Using the deuterium isotope composition of permafrost meltwater to constrain thermokarst lake contributions to atmospheric $\mathrm{CH} 4$ during the last deglaciation, J. Geophys. Res.-Biogeosci., 117, G01022, doi:10.1029/2011JG001810, 2012.

Brown, J., Ferrians Jr, O., Heginbottom, J., and Melnikov, E.: Circum-Arctic map of permafrost and ground-ice conditions, US Geological Survey Circum-Pacific Map, 1997.

Carte, A.: Air bubbles in ice, Proceedings of the Physical Society, 77, 757-768, doi:10.1088/0370-1328/77/3/327, 1961.

Cole, J., Prairie, Y., Caraco, N., McDowell, W., Tranvik, L., Striegl, R., Duarte, C., Kortelainen, P., Downing, J., Middelburg, J., and Melack, J.: Plumbing the Global Carbon Cycle: Integrating Inland Waters into the Terrestrial Carbon Budget, Ecosystems, 10, 172-185, doi:10.1007/s10021-006-9013-8, 2007.
Craig, H., Wharton, R., and McKay, C.: Oxygen supersaturation in ice-covered Antarctic lakes: Biological versus physical contributions, Science, 255, 318-321, doi:10.1126/science.11539819, 1992.

Emmerton, C. A., Lesack, L. F. W., and Marsh, P.: Lake abundance, potential water storage, and habitat distribution in the Mackenzie River Delta, western Canadian Arctic, Water Resour. Res., 43, W05419, doi:10.1029/2006WR005139, 2007.

Grigoriev, N.: The temperature of permafrost in the Lena delta basin - deposit conditions and properties of the permafrost in Yakutia, 97-101, in Russian, 1960.

Grosse, G., Romanovsky, V., Walter, K., Morgenstern, A., Lantuit, H., and Zimov, S.: Distribution of thermokarst lakes and ponds at three yedoma sites in Siberia, in: Proceedings of the 9th International Conference on Permafrost, Fairbanks, Alaska, 29 June-3 July 2008 , 551-556, 2008.

Helbig, M., Boike, J., Langer, M., Schreiber, P., Runkle, B. R., and Kutzbach, L.: Spatial and seasonal variability of polygonal tundra water balance: Lena River Delta, northern Siberia (Russia), Hydrogeol. J., 21, 133-147, doi:10.1007/s10040-012-09334, 2013.

Hugelius, G., Tarnocai, C., Broll, G., Canadell, J. G., Kuhry, P., and Swanson, D. K.: The Northern Circumpolar Soil Carbon Database: spatially distributed datasets of soil coverage and soil carbon storage in the northern permafrost regions, Earth Syst. Sci. Data, 5, 3-13, doi:10.5194/essd-5-3-2013, 2013.

Karlsson, J., Giesler, R., Persson, J., and Lundin, E.: High emission of carbon dioxide and methane during ice thaw in high latitude lakes, Geophys. Res. Lett., 40, 1123-1127, doi:10.1002/grl.50152, 2013.

Killawee, J., Fairchild, I., Tison, J.-L., Janssens, L., and Lorrain, R.: Segregation of solutes and gases in experimental freezing of dilute solutions: Implications for natural glacial systems, Geochim. Cosmochim. Ac., 62, 3637-3655, doi:10.1016/S00167037(98)00268-3, 1998.

Koven, C. D., Ringeval, B., Friedlingstein, P., Ciais, P., Cadule, P., Khvorostyanov, D., Krinner, G., and Tarnocai, C.: Permafrost carbon-climate feedbacks accelerate global warming, P. Natl. Acad. Sci., 108, 14769-14774, doi:10.1073/pnas.1103910108, 2011.

Kutzbach, L., Wagner, D., and Pfeiffer, E.-M.: Effect of microrelief and vegetation on methane emission from wet polygonal tundra, Lena Delta, Northern Siberia, Biogeochemistry, 69, 341-362, doi:10.1023/B:BIOG.0000031053.81520.db, 2004.

Kutzbach, L., Wille, C., and Pfeiffer, E.-M.: The exchange of carbon dioxide between wet arctic tundra and the atmosphere at the Lena River Delta, Northern Siberia, Biogeosciences, 4, 869-890, doi:10.5194/bg-4-869-2007, 2007.

Lachenbruch, A. H.: Mechanics of thermal contraction cracks and ice-wedge polygons in permafrost, Geol. S. Am. S., 70, 1-66, doi:10.1130/SPE70-p1, 1962.

Langer, M., Westermann, S., Muster, S., Piel, K., and Boike, J.: The surface energy balance of a polygonal tundra site in northern Siberia - Part 1: Spring to fall, The Cryosphere, 5, 151-171, doi:10.5194/tc-5-151-2011, 2011a.

Langer, M., Westermann, S., Muster, S., Piel, K., and Boike, J.: The surface energy balance of a polygonal tundra site in northern Siberia - Part 2: Winter, The Cryosphere, 5, 509-524, doi:10.5194/tc-5-509-2011, 2011 b. 
Laurion, I. and Mladenov, N.: Dissolved organic matter photolysis in Canadian arctic thaw ponds, Environ. Res. Lett., 8, 3502635037, doi:10.1088/1748-9326/8/3/035026, 2013.

Laurion, I., Vincent, W. F., MacIntyre, S., Retamal, L., Dupont, C., Francus, P., and Pienitz, R.: Variability in greenhouse gas emissions from permafrost thaw ponds, Limnol. Oceanogr., 55, 115133, doi:10.4319/lo.2010.55.1.0115, 2010.

Liebner, S., Zeyer, J., Wagner, D., Schubert, C., Pfeiffer, E.-M., and Knoblauch, C.: Methane oxidation associated with submerged brown mosses reduces methane emissions from Siberian polygonal tundra, J. Ecol., 99, 914-922, doi:10.1111/j.13652745.2011.01823.x, 2011.

Lipp, G., Körber, C., Englich, S., Hartmann, U., and Rau, G.: Investigation of the behavior of dissolved gases during freezing, Cryobiology, 24, 489-503, doi:10.1016/0011-2240(87)90053-8, 1987.

McGuire, A. D., Anderson, L. G., Christensen, T. R., Dallimore, S., Guo, L., Hayes, D. J., Heimann, M., Lorenson, T. D., Macdonald, R. W., and Roulet, N.: Sensitivity of the carbon cycle in the Arctic to climate change, Ecol. Monogr., 79, 523-555, doi:10.1890/08-2025.1, 2009.

Morgenstern, A., Ulrich, M., Günther, F., Roessler, S., Fedorova, I. V., Rudaya, N. A., Wetterich, S., Boike, J., and Schirrmeister, L.: Evolution of thermokarst in East Siberian icerich permafrost: A case study, Geomorphology, 201, 363-379, doi:10.1016/j.geomorph.2013.07.011, 2013.

Muster, S., Langer, M., Heim, B., Westermann, S., and Boike, J.: Subpixel heterogeneity of ice-wedge polygonal tundra: a multi-scale analysis of land cover and evapotranspiration in the Lena River Delta, Siberia, Tellus B, 64, 1-19, doi:10.3402/tellusb.v64i0.17301, 2012.

Muster, S., Heim, B., Abnizova, A., and Boike, J.: Water body distributions across scales: a remote sensing based comparison of three arctic tundra wetlands, Remote Sens., 5, 1498-1523, doi:10.3390/rs5041498, 2013.

Negandhi, K., Laurion, I., Whiticar, M. J., Galand, P. E., Xu, X., and Lovejoy, C.: Small Thaw Ponds: An Unaccounted Source of Methane in the Canadian High Arctic, PLoS ONE, 8, e78204, doi:10.1371/journal.pone.0078204, 2013.

O’Connor, F. M., Boucher, O., Gedney, N., Jones, C. D., Folberth, G. A., Coppell, R., Friedlingstein, P., Collins, W. J., Chappellaz, J., Ridley, J., and Johnson, C. E.: Possible role of wetlands, permafrost, and methane hydrates in the methane cycle under future climate change: A review, Reviews of Geophysics, 48, RG4005, doi:10.1029/2010RG000326, 2010.

Phelps, A. R., Peterson, K. M., and Jeffries, M. O.: Methane efflux from high-latitude lakes during spring ice melt, J. Geophys. Res.Atmos., 103, 29029-29036, doi:10.1029/98JD00044, 1998.
Sachs, T., Wille, C., Boike, J., and Kutzbach, L.: Environmental controls on ecosystem-scale $\mathrm{CH} 4$ emission from polygonal tundra in the Lena River Delta, Siberia, J. Geophys. Res.-Biogeosci., 113, G00A03, doi:10.1029/2007JG000505, 2008.

van Hulzen, J., Segers, R., van Bodegom, P., and Leffelaar, P.: Temperature effects on soil methane production: an explanation for observed variability, Soil Biol. Biochem., 31, 1919-1929, doi:10.1016/S0038-0717(99)00109-1, 1999.

Walter Anthony, K. M. and Anthony, P.: Constraining spatial variability of methane ebullition seeps in thermokarst lakes using point process models, J. Geophysi.l Res.-Biogeosci., 118, 10151034, doi:10.1002/jgrg.20087, 2013.

Walter Anthony, K. M., Vas, D. A., Brosius, L., Chapin, F. S., Zimov, S. A., and Zhuang, Q.: Estimating methane emissions from northern lakes using ice-bubble surveys, Limnol. Oceanogr-Meth., 8, 592-609, doi:10.4319/lom.2010.8.0592, 2010.

Walter, K. M., Zimov, S. A., Chanton, J. P., Verbyla, D., and Chapin, F. S. : Methane bubbling from Siberian thaw lakes as a positive feedback to climate warming, Nature, 443, 71-75, doi:10.1038/nature05040, 2006.

Wei, P., Huang, C., and Lee, K.: Nucleation of bubbles on a solidification front-experiment and analysis, Metallurgical and Materials Transactions B, 34, 321-332, doi:10.1007/s11663-003-0078$\mathrm{x}, 2003$.

Wetterich, S., Schirrmeister, L., Meyer, H., Viehberg, F., and Mackensen, A.: Arctic freshwater ostracods from modern periglacial environments in the Lena River Delta (Siberian Arctic, Russia): geochemical applications for palaeoenvironmental reconstructions, J. Paleolimnol., 39, 427-449, doi:10.1007/s10933007-9122-1, 2008.

Wik, M., Crill, P. M., Bastviken, D., Danielsson, Å., and Norbäck, E.: Bubbles trapped in arctic lake ice: Potential implications for methane emissions, J. Geophys. Res.-Biogeosci., 116, G03044, doi:10.1029/2011JG001761, 2011.

Wille, C., Kutzbach, L., Sachs, T., Wagner, D., and Pfeiffer, E.-M.: Methane emission from Siberian arctic polygonal tundra: eddy covariance measurements and modeling, Glob. Change Biol., 14, 1395-1408, doi:10.1111/j.1365-2486.2008.01586.x, 2008.

Yoshimura, K., Inada, T., and Koyama, S.: Growth of Spherical and Cylindrical Oxygen Bubbles at an Ice-Water Interface, Crystal Growth \& Design, 8, 2108-2115, doi:10.1021/cg070251k, 2008.

Zimov, S., Voropaev, Y. V., Semiletov, I., Davidov, S., Prosiannikov, S., Chapin, F. S., Chapin, M., Trumbore, S., and Tyler, S.: North Siberian lakes: A methane source fueled by Pleistocene carbon, Science, 277, 800-802, doi:10.1126/science.277.5327.800, 1997.

Zubrzycki, S., Kutzbach, L., Grosse, G., Desyatkin, A., and Pfeiffer, E.-M.: Organic carbon and total nitrogen stocks in soils of the Lena River Delta, Biogeosciences, 10, 3507-3524, doi:10.5194/bg-10-3507-2013, 2013. 